Maryna Lazareva,

D.Sc., Professor, National University of «Kyiv-Mohyla Academy», Ukraine

\title{
POSITIONING MATRIX AS AN ASSESSMENT TOOL FOR SECURITY LEVEL OF A PRODUCT PORTFOLIO COMPETITIVE POSITION
}

\begin{abstract}
The main objective of the study is to develop a tool for assessing the balance of the company's product portfolio, with which you can determine the security of its competitive position. As such a tool is proposed matrix positioning. The indicator of the balance of the product portfolio is the golden ratio. The relevance of this study lies in the fact that currently there is no generally accepted criterion for determining the degree of balance in the product portfolio, and that the existing matrix analysis tools do not fully provide an adequate assessment of the security of a competitive position. The study of the topic in the article is carried out in the following logical sequence: the author proves the legitimacy of using the golden ratio as the main indicator for assessing the balance of the product portfolio, then suggests the algorithm for assessing the security of the product portfolio developed by the author; further author considers modern methods for evaluating the product portfolio, then provides a method for constructing a matrix of positioning and interpretation of results using practical examples; further, there are the conclusions about the applicability of the proposed approach and tool. The article proposes the author's version of the solution to the issue of assessing the security of the competitive position of the product portfolio. A portfolio analysis tool has been developed - a positioning matrix, which involves a different combination of market growth rates and the share of a specific product/product group/brand on it. In this case, the net value of the product portfolio is calculated as a function of the company's business value. Formulated criteria for the balance of the product portfolio, based on the proportion of the "golden ratio». The competitive position of the product portfolio will be protected when the growth rate of the product/product group/brand is equal to or exceeds the market growth rate and the market share for the product group over time either remains at the same level or grows. The results of the study can be useful for the further development of approaches and tools for assessing the competitive position of the company. The positioning matrix has already shown its potential in practice and will be useful in practice when assessing the company's competitive position as a basic or complementary tool.
\end{abstract}

Keywords: competitive position, golden ratio, positioning matrix, balanced product portfolio, product portfolio.

Introduction. One of the company's low-efficiency factors is poorly structured product portfolios and the absence of established criteria for their evaluation and, as a result, the low competitive position of brands/product groups and the company. A similar situation can be observed regarding the balance of a product portfolio. On a practical level, products are divided into groups in order of importance for the company, for example, the core, complementary, strategic, group of products being developed/new products, etc. The level of importance is determined by various factors that reflect the product life cycle, the market life cycle stage at which products currently exist, brand strength, revenue from the sales, etc. The company decides on the ratio of these types of products in its portfolio at its discretion. For example, a portfolio is considered balanced if the main product makes up $70-85 \%$ of all goods produced by the company. It is advisable to consider the product portfolio in terms of product maturity, but it is quite difficult to determine the degree of maturity of a product in practical terms. Such analysis requires a significant amount of time and effort, especially if the company has a large range of products.

It is proposed to introduce a proportion of the «golden ratio» as an evaluation criterion for the structure of the product portfolio, since «harmony as an objective reality exists and must manifest itself in various systems, including economics; harmonization is defined as a peculiar process of any complex system striving to harmonious proportions of its constituents with the whole» (Sheniagin, 2013, p. 1). «The golden coefficient is used by nature to constitute its parts, ranging from large to small. Modern science believes that the Universe develops along the so-called golden spiral, which is based on the golden coefficient. This spiral has no end and no beginning. Both its larger and smaller waves have the same shape. Smaller

Cite as: Lazareva, M. (2019). Positioning Matrix as an Assessment Tool for Security Level of a Product Portfolio Competitive Position. Marketing and Management of Innovations, 4, 82-97. http://doi.org/10.21272/mmi.2019.4-07 
coils never converge at one point, and large ones spread out in space limitlessly. This describes the trajectories of movement of comets and meteorites, the increase in the number of bacteria, the shape of the pineapple and the shell of a mollusc, and even the structure of the human ear» (Ehrlich, 1996, p. 64). «It is assumed that the «golden ratio» contains not only fundamental proportions but also basic metrics capable of harmonizing the relations of social agents in the world» (Ivanus and Pragnishvili, 2004, p. 3).

The mathematician Leonardo Fibonacci discovered several properties of the golden ratio and suggested a sequence of numbers. The ratio of any number of the sequence to the next approximates 0.618 (after the first four numbers). For example: $1 / 1=1.00 ; 1 / 2=0.50 ; 2 / 3=0.67 ; 3 / 5=0.60 ; 5 / 8=0.625$; $8 / 13=0.615 ; 13 / 21=0.619$ and so on. The coefficient of correlation 1.618 or 0.618 was also known to ancient Greek and ancient Egyptian mathematicians, who called it the «golden coefficient» (We can trace it in music, visual arts, architecture and biology. The Greeks used the principle of the "golden ratio» during the construction of the Parthenon, the Egyptians - the Great Pyramid at Giza. Its properties were well known to Pythagoras, Plato and Leonardo da Vinci (Murphy, 1996). Modern designers rather widely use the golden ratio in their decision-making (see, eg: (Pentago, 2018)). Mack Winnie focuses on the influence of the dynamic symmetry of the design of $D$. Hambidge on three generations of artists, examining the works of selected American artists from 1920 to the present, also studying the effect of dynamic symmetry in other areas (McWhinnie, 1986)) or the «golden ratio». In technical analysis, this proportion has long served as a benchmark for many techniques for trend interpretation. Particularly, the Elliott Wave Theory (Fibonacci sequence) is based on this proportion.

This proportion can be applied in many areas of management and marketing, including harmonious management (Ivanus, 2012, p. 34). The use of the golden ratio in management is only starting to attract the attention of researchers. A generally accepted matrix analysis ratio, which should determine the structure of a balanced product portfolio does not exist yet.

The article has the following structure. In the first section we cover the methodological base of portfolio analysis; define a balanced approach to the product portfolio; justify the use of the "golden ratio» in assessing the balance of the product portfolio. In the second section, we propose an algorithm for determining the level of security of the company's product portfolio competitive position. The third section proposes an original matrix analysis tool - a positioning matrix for the subsequent assessment of the level of security of the competitive position of the product portfolio and the construction of a portfolio management strategy. In the fourth section, a positioning matrix for a real enterprise is built to show the practical implementation of the proposed tool. In the last part, conclusions are drawn about the study and the feasibility of the proposed approaches and tools in both science and application.

Literature Review. We suggest the use the "golden ratio» as the basis for determining the balance of the portfolio, since it is the basic constructional principle for a large number of the phenomena of our life, starting from the cells of any living organism ending with the most complex structures of a human body (see, for example: (Renyi, 1980). For many centuries, mankind has used this ratio in architecture, sculpture, and now we start using it in other areas of our life.

The use of proportion $\varphi$ for research and practical applications originates in the theory of systems (see, for example: (Ivanus, 2012; Korobko, 1998; Yasinsky, 2008). In 1964, A. P. Stakhov and I. V. Vitenko discovered generalized Fibonacci numbers and generalized «golden ratios» (Stakhov, 2011). Together with A. Olsenem A. Stakhov has developed the mathematics of harmony (see, for example: (Stakhov and Olsen, 2009)). In 1984, E. M. Soroko formulated a concept which incorporates «Law of structural harmony of systems» with the harmonious proportion as the basis for a quantitative measure: «Generalized golden ratios are invariable; based on and through this in the process of self-organization natural systems acquire a harmonious structure, stationary mode of existence, and structural-functional ... stability» (Ivanus, 2012, p. 34). Soroko (Soroko, 2006) has put forward a hypothesis (System harmony law) that this discovery may be of utmost importance for synergetics, the study of processes in self-organizing systems. "One of the 
ways to solve the problem of the reliability of modern computers is to introduce the concept of superabundance. At the same time, it is necessary to draw attention to the system of calculation with an irrational fundamental principle based on Fibonacci numbers and the golden ratio, which possess such superabundance (incidentally, the conventional binary system can be an example of such calculation system), which allows us to create dependable noise-resistant computers» (Ivanus, 2004, p. 12). According to the general systems theory, an open dynamic system is created/exists with reserves. For example, a manufacturing enterprise should have a reserve stock of production capacity.

«The golden principle also corresponds with the optimal entry of one system into another, which contradicts the «randomness» principle of the living systems organization. That is, nature always finds the optimal solution concerning the expenditure of energy ... The examples given indicate that any system is subject to the universal law of structuring in nature and in statistical laws, which enables these systems to dynamically develop with minimal energy expenditure. And, as our studies have shown, economic systems are not an exception to the rule either» (Kriuchkova, 2008).

It should be pointed out that I. V. Pragnishvili and A. I. Ivanus have discovered and proved that «for competing processes in the economy, the point of equilibrium is the ratio of $62.0 \%: 38.0 \%$ » while researching competitive markets (Pragnishvili and Ivanus, 2004; Ivanus, 2012). The most efficient way of income and resources distribution corresponds with the principles of the «golden ratio». The authors have introduced the concept of a «harmonious market» to the scientific community: "a harmonious market is an economic system in which there is a maximum number of links between its elements that correspond with the proportions of the «golden ratio» (Pragnishvili and Ivanus, 2004, p. 3). Such a market is a system optimized to minimize the necessary cost needed to ensure its sustainability. Of course, such a market is an idealized model, but it makes it possible to compare real market processes with it, study the behaviour of participants on the market, prices development and dynamics, and assists with making decisions.

N. A. Loginova and I. A. Nikitina apply the principle of harmony («golden ratio») to develop a market theory in application to transport (Loginova and Nikitina, 2015). The authors come to a conclusion that the «golden ratio» has unique properties regarding system forming that can be used as a toolkit for the creation, functioning management and development of the transport services market (Loginova and Nikitina, 2015, p. 64). In a paper published in 2010 (Kirillova and Ziyangulova, 2010) the use of the «golden ratio» principle in harmonizing the structure of an enterprise is justified. The authors develop a harmonious balance model for an absence of long-term liabilities case. The thesis research of D. E. Khitskova (Khitskov, 2012) uses the principle of the «golden ratio» to harmonize relations between the subjects of a holding and to resolve conflicts between different levels of management of a group of companies. N. V. Pankova states: «Intrinsically, the task of optimizing the franchise is solved using data about the sales volumes for a certain period utilizing the entropy indicator based on the «golden ratio» rule. The value of entropy indicator should coincide with the constant step of the Golden proportion of 0.62» (Pankova, 2013, p. 344).

«Research and analysis of the commercial firm's activity have made it possible to establish that the consistency and harmony of the constituents of business in these proportions enhance adaptive qualities of the company, which ensure its successful development. Companies that have already used the method of managing business using the golden ratio technique, lowered cost of running business by $15-20 \%$, increased goods and services production and sales rates by $10-20 \%$, improved the quality of labour service, and increased the asset turnover rate by 30\%» (Vlasova, 2006). A. M. Semiglazov and V. A. Semiglazov (Semiglazov A. M. and Semiglazov V. A., 2009) elicit the use of the "golden ratio» in various economic correlations.

V. Dimovsky and M. Wuhan (Dimovski and Wuhan, 2012) consider the possibility of applying the golden ratio for management: planning, controlling, organizational engineering, and leadership (i.e. in motivational programs). 
B. Naggy and J. Tuff (Nagji and Tuff, 2012) argue that while considering innovation portfolio balance, managers should consider the results of their research. The authors analyzed companies in industry, technology and consumer goods sectors to determine whether any specific distribution of resources for major, complementary and transformational initiatives is related to significantly higher productivity, reflected in the stock price of the company. It turned out that there is a certain pattern: companies that have allocated about $70 \%$ of their innovation dedicated resources to major initiatives, $20 \%$ to complementary and $10 \%$ to transformational, have surpassed their peers, usually reaching the P/E (price to earnings ratio) premium of $10 \%$ to $20 \%$. These proportions are close to the golden ratio.

F. Thomas and A. Crystal. (Thomas and Chrystal, 2013) research the use of the golden ratio in marketing. The authors offer two basic indexes: for packaging -2.62 and prices -1.62 and show that this pair of indexes satisfy the needs of customers the best. Thus, the golden ratio can be considered a marketing tool that vendors can use in the interests of their customers. M. Tabatabay (Tabatabaei, 2016) argues that the golden ratio is present in management as an «invisible» indicator that can be used both in the management process and in the efficiency of resource use.

A group of marketing researchers (Nikolicetal, 2011) examines the relationship between the «golden ratio» and consumer aesthetic preferences and explores its practical application regarding forming a market offer for the consumer. Due to the increasingly diverse market supply that is provided for consumers, every detail of an offer must be thought out to attract consumer's attention.

The author of the bestseller on neuromarketing R. Dooley notes in his blog that from neuromarketing it is interesting to know that harmonious proportions for the shapes of objects are «embedded» in our brain. This does not mean that each element in each object should have a width to height ratio of 1.618 . In some cases, deliberate deviations may have a greater impact. Other proportions may as well be perceived by the brain. However, graphic designers and commercial artists should be aware of our brain's preferences for this proportion and use it when necessary (Dooly, 2011).

«Harmonization is appropriate where there is structural diversity. The «golden ratio» can be viewed as a fundamental relationship for the harmonization of the organizations' economics consisting of various divisions. Assured optimal (harmonized) diversity, which ensures the systemic quality and, consequently, functional efficiency results in minimizing unproductive costs. The laws of Measure, Harmony, "Golden Ratio» make it possible to build an economy, the essence of which is the optimal (harmonious) distribution of resources» (Soroko, 2006, p. 64).

We have chosen the principle of the "golden ratio» as the basis since it possesses the superabundance and stability that allow self-organizing systems to be organized. Creating a redundant system (system with superabundance according to the general theory of systems) implies the use of the "golden ratio» in the structures of the system (the company's asset portfolio, product portfolio, organizational, financial, technological processes/structures, etc.), rather than an arbitrary number of redundant areas of business activity, capacity, excess financial, human and other resources, etc. At the same time stability implies the preservation of the basic parameters of the firm-system in a range that allows for reacting to external and/or internal factors at a minimal loss.

The use of the "golden ratio» to assess how well is the product portfolio balanced makes it possible to ensure the security of the competitive position of the company. Such a portfolio is, to some extent, protected from risks and, at the same time, provides the company with an opportunity for development, adequate development of the environment, which we treat as a complex system.

In our case (The breakdown of products/brands into groups can be performed in any form adopted by the company, using an approach of the portfolio analysis adopted by the company), the set of main product groups/brands that provide a constant cash inflow at this moment (that create a constant increase in business value) can be considered the most significant characteristic of a company as a system; at the same time any sets of new products that currently do not generate value can be considered the opposite, 
they absorb value at the current point in time. Therefore, it is important to find the right proportion within the system (company) to ensure the balance of the product portfolio. The best portfolio will have the ratio in which the influence of one of the opposites on the other will be within the specified proportions of the «golden ratio».

We shall define the harmonious company model: harmonious company is a company in which all significant structural relations conform to the proportions of the "golden ratio», for example, the ratio of proprietary capital and loan capital, the ratio of the main to the bonus part of employee remuneration, the number of core and complementary business activities in the portfolio structure, etc.

Methodology and research methods. The purpose of the article is to develop an innovative tool for assessing the sustainability of the company's product portfolio, which can help one determine the level of security of its competitive position. Positioning matrix is the tool suggested. The golden ratio acts as an indicator of the product portfolio balance.

As a practical matter, $A B C$ and $X Y Z$ methods are widely used to analyze the company's product line. $A B C$ analysis involves a breakdown of item positions (or groups of products/brands) into groups according to their importance. The criteria for classifying goods into a group may be, for example, its trade turnover. It is a useful tool for determining the assortment policy, which can serve as a basis for further marketing research from the perspective of determining the competitive position of a product. The Pareto principle is used as an evaluation criterion: $20 \%$ of products provide $80 \%$ of the trade turnover.

The XYZ method allows for the classification of the company's resources regarding the nature of their consumption and the accuracy of forecasting changes in their demand during a set period. This method is more complex in terms of calculations. First, the coefficients of variation for the analyzed resources are determined, and then they are sorted according to the increase of these coefficients. After that, resources are sorted into categories $X, Y$ and $Z$. The analysis results can be presented graphically. This method also allows for the range of products analysis regarding sales of a product, and convenient graphical representation simplifies the analysis. This method, like the previous one, can serve as a basis for further research by a marketing specialist. All matrices have been developed under real-life conditions of practical activity of corporations.

The methods that generalize and complement the ones mentioned above are the tools for matrix analysis of product portfolios. One of the first matrices that have received wide practical application is the "growth - market share» matrix, or BCG matrix (Boston Consulting Group). The methodology of it is based on several assumptions that make this matrix a solid tool and at the same time act as the target of criticism for opponents (see, eg: (Seeger, 1984)) of its use: «Net profit and available funds are a function of market share ... Growth requires an infusion of additional funds to finance additional assets ... A high market share must be earned or purchased ... Merchandise markets can not grow indefinitely. The return from the growth should come during a period growth deceleration, otherwise, you should not even account for it ...» (Minzberg, 2013, pp. 93-94).

The statement that is that «if a portfolio has assets with different growth rates of sales volumes and different market shares, then it will ensure harmonious cash flow, i.e., it will create a balanced portfolio» serves as the basis of this approach. G. Mintzberg (Minzberg, 2013, pp. 93-96) gives an interpretation of the approach by the founder of the Boston consulting group, B. Henderson, who believes that a balanced portfolio should consist of «Stars», that is, businesses that have a high share of the fast-growing market; of the «Cash cows», i.e., businesses that generate the main cash flow (high market share, low growth potential) and «Problem children» (low market share, high business growth potential). The proportions of such assets in the business portfolio are not mentioned. The matrix is used for assessment of the business portfolio, as well as for the assessment of the product portfolio. 
The analysis based on the BCG method relies on two assumptions: the first is related to the existence of experience effects, the second is related to the product life cycle model (Kulinich, 2005, p. 44). Assumptions are the following:

1) a large relative market share presupposes an expenditure advantage over direct competitors. At the same time, the biggest competitor will receive the largest profit share at the market price level provided the application with the experience curve. That is the experience effect. Conversely, a smaller relative market share implies a market player's lagging in terms of costs. The conclusion from this assumption is that greater cash flow should be expected from goods with a larger relative market share than from products with a smaller market share;

2) a growing market presupposes investing in development, increasing production capacity, conducting advertising campaigns, etc. The product presented on a mature market generates sufficient consistent cash flow and does not require additional investments. In this regard, a model of the product life cycle is used: it indicates the necessity for a balanced combination of goods at different stages of the product life cycle.

Except for the main drawback - only two indicators, the BCG method does not determine how many assets and in what proportion should be included in the portfolio, which means that actual formalization of the concept of balance is lacking.

The McKinsey - General Electric portfolio analysis matrix (often called the GE Matrix) is an advanced version of the BCG matrix since the indicators are selected based on the specific situation. The GE matrix assumes a larger amount of data incorporated into the model than the Boston matrix. The market growth indicator is transformed in this model into a multifactorial concept of «market attractiveness», and the «market share» indicator becomes «strategic position». Unlike the BCG matrix, it does not consider the logical connection between competitive ability indicators and cash flows. A feature of the developed model is that it can be applied at all stages of the demand life cycle under various competition conditions. In our opinion, this matrix has another drawback - the subjectivity of assessments, since each indicator is determined and evaluated by an expert.

Results. To form an effective technology for portfolio analysis, it is necessary to develop and substantiate an application-oriented toolkit that can complement existing techniques using a morphological positioning matrix. The latter is sensible to be built to determine the degree of protection of the company's product/brand portfolio from the standpoint of protecting the competitive position of product groups/ brands that are part of the company's overall product/brand portfolio.

The competitive position of the company's product/brand portfolio is the company's business value functional relation. Respectively, when it comes to the increase in business value, the competitive position of the product portfolio demonstrates growth and vice versa. It should be borne in mind that, when it comes to protecting the business value, most professionals have in mind only the legal protection of assets. There is a lot of research and practical developments that allow us, to a certain degree, protect property and provide the most favourable conditions for the purpose's optimal taxation for the owners. Since this concerns legal aspects, we will not address these issues. From an economic point of view, cost protection is talked about most often when it comes to the systems of internal control and risk management. Let us note that in business this is stated in special regulations (for example, the company IFC has developed guidelines on operational risk management and offers to implement them in practice (IFC rules)). And the protection of the property is the main principle of an effective management system.

Within the given context we will consider the business value/competitive position secure from the perspective of competitive position, if the growth rate of the product/brand group/brand of the product portfolio is equal to or higher than the market growth rate and the market share over time either remains at the same level or increases. To determine the degree of security of the product portfolio competitive 
position we will use the following algorithm of five basic stages of the economic-organizational and economic-statistical procedures in the context of solving the undertaken problem (Figure 1).

STEP 1. Assessing the situation concerning the competitive position of each group of products/brands in the product portfolio. Determining the market capacity for each product/brand group.

STEP 2. Predicting the competitive position of each group of products/brands that are included in the portfolio. Determining the market share.

STEP 4. Calculating the net value of the product portfolio, considering the predicted increased values in sales for each of the product groups/brands included in the portfolio
STEP 3. Predicting the market development for the next 3-5 years, considering the capacity of the markets on which the products/brands are present. Considering the forecast of the market growth rate. Within the given context we can assume that it is enough to determine only the growth rate of the market.

STEP 5. Analysing the efficiency of basic product groups/brands managing within their competitive position in the future.

Figure 1. The popularity of the "online insurance» request in the google search engine Source: own research.

To determine the security of the competitive position of the product portfolio, the following algorithm is proposed:

1) analysing the positioning of each product/product group/brand included currently in the product portfolio present on the market: to do this we determine the market capacity and the share of each product/product group/brand on the market;

2) making a forecast of the growth rate of the industry/product category for the specified period;

3) making a forecast of the competitive position of each of the products/group of products/brands included in the portfolio: to do this we calculate market shares;

4) calculating the net cash flow of the product/product group/brand of the product portfolio;

5) making a positioning matrix for the product portfolio;

6) determining the degree of balance in the product portfolio; comparing the proportions obtained between the core and complementary product groups/brands with the proportion of the "golden ratio»;

7) to analyse the security of the net value of the product portfolio we determine which part of the value is secure, which is ambiguous, and which is insecure; analysing the cost structure, determining whether it corresponds to the proportion of the «golden ratio»;

8) if the structure of the portfolio and/or the structure of the analysed value is notably far from the proportion of the "golden section», then we return to the first step and analyse the possibility of introducing any corrections to the portfolio and, if necessary, carry out the corrective actions. If such actions are not unfeasible at this stage of portfolio development, proceed to the next step (The following two steps show how the proposed algorithm is integrated into the general strategic management system);

9) choosing the desired strategy under the basic strategies suggested when applying the positioning matrix. Based on the strategy we form a product portfolio and define goals achieving of which is necessary to balance the portfolio;

10) developing motivational programs for top management and departments specialists that affect the structure and value of the product portfolio.

A crucial characteristic to consider while developing and managing a product portfolio is that it ensures the profitability to the business owner and the desired rate of growth of this profitability in the short and 
long term. To do this, the product portfolio needs to be balanced by accelerator products that ensure constant cash inflow in the short term as well as products that are just introduced into the portfolio and will provide the required level of profitability in the future. The portfolio must include products that are at different stages of their life cycle and are at different efficiency levels (we keep the «growth - market share» matrix logic). We should draw attention to the fact that accelerator products may not necessarily have a high level of profitability, but they create cash inflow driven by turnover, while new products may have high profitability or, conversely, low profitability, depending on which pricing strategy for a new product is adopted for entering the market. In every instance, any product portfolio requires variety. This ensures the portfolio's balance. A balanced product portfolio requires an optimal combination of the profitability level (desired by the owner) in the current and long-term periods, a set growth rate (to achieve a certain level of portfolio value in a timeframe determined by owner), a certain level of risk and liquidity. The following criteria should be considered for determining whether the product portfolio is balanced: $38 \%$;

1) the ratio of core to complementary products/product groups/brands is close to the proportion $-62 \%$ :

2) the ratio of the security value of the portfolio/competitive position to the rest of the portfolio/competitive value will approach the proportion of the «golden ratio».

A positioning matrix that has given a good account of itself for assessing the business portfolio of a group of companies (Lazareva, 2014) with some modifications can be used to analyse the product portfolio and/or brand portfolio. The idea of this matrix arose while the author was working with the «Slav AG» group of companies. It is a group with a diversified portfolio of businesses. Heads of lines of activity (businesses) prepared reports on their activities. These were traditional reports that contained information about revenue, its growth rates, profits, and so on. But it was not clear whether this was positive or negative, how much or how little. A strategic analysis of the group's business portfolio was conducted. The use of well-known BKG and McKinsey matrices did not helpfully understand whether the group was developing well or poorly. The situation required new approaches. Then the idea to compare each line of business with the growth rates of the corresponding markets appeared. Naturally, this was reflected in the market shares of products. The author developed a matrix that allowed analysing the quality of business growth. If a business grows faster than the market and the market share grow over time, it is effective growth. Based on this statement, a strategic goal was set for a period of business growth - 5 years. Performance benchmarks and motivational programs were developed by it. The golden ratio was chosen as a criterion for the balance of the business portfolio. With a balanced portfolio, the ratio of the security value of the business to the ambiguous and insecure should be in proportions resembling the golden ratio. The success rate of the tool is shown in Table 1.

Table 1. Results of assessing the business portfolio balance in the group of companies «Slav AG» (simplified version - the cost of the business was calculated using discounted cash flows, excluding inflation changes), 2005-2011

\begin{tabular}{|c|c|c|c|c|c|c|c|}
\hline & 2005 & 2006 & 2007 & 2008 & 2009 & 2010 & 2011 \\
\hline $\begin{array}{c}\text { The ratio of protected value to } \\
\text { ambiguous and unprotected, \%: \% }\end{array}$ & $10: 90$ & $24: 76$ & $30: 70$ & $61: 39$ & $60: 40$ & $65: 35$ & $63: 37$ \\
\hline $\begin{array}{c}\text { Growth rate of sales revenue } \\
\text { (consolidated for the Group of } \\
\text { companies), \% }\end{array}$ & 3 & 5 & 3 & 20 & 22 & 24 & 23 \\
\hline
\end{tabular}

Sources: Compiled according to data of the «Slav AG» company group.

In 2007, the portfolio structure of the previous three years was analysed, and a decision was made to use the "golden ratio» as an indicator of balance. This was reflected in the company's development strategy for the next 4 years. 2009-2011 The result of the development strategy implementation is shown. 
For this study, we modified the matrix presented in such a way that it can be used to assess the security of the product portfolio competitive position. We call the proposed tool - product portfolio positioning matrix. Managing business portfolios of holdings and product portfolios of a company/holding have a lot in common. For example, matrix analysis is used both for analysing business portfolios and for product portfolios. Therefore, when developing matrices, the same principle is applied. But different approaches in the interpretation of the results are used. While analysing the business portfolio, decisions are made on the participation of a group of companies in various sectors, on mergers, acquisitions, sale of businesses, etc., that is, decisions are made on issues related to the development of the business portfolio of a group of companies. This is long-term research, i.e. for 3-5-8 years. To do this the future cash flow is estimated and the business value of each of the businesses in the portfolio is calculated (after deduction of internal turnover). When analysing the product portfolio, we consider, first of all, the competitive position of a particular group of goods, brands, goods and decisions are made on adjusting product positioning strategies on the market, on rebranding, etc. This is mostly done for shorter periods up to 1 year. We can consider the competitive position of the product portfolio secure when the growth rate of the product/product group/brand is equal to or higher than the market growth rate and the market share of the product/product group/brand over time either remains at the same level or increases.

In the positioning matrix, the vertical axis is assigned the market growth rate index, the horizontal axis - the market share for each of the products/group of products/brands. The matrix assumes a different combination of market growth rates and the share of a specific product/product group/brand on it. Therefore, there are nine possible combinations of the selected parameters, which are represented in the matrix in the form of quadrants 1-9. We denote the growth rate of the market $-r_{m}$; the growth rate of a product/product group/brand $-r_{b}$; market share during the reference period - $s_{0}$; in the planned period $s_{p}$. This is how the actual matrix looks like (Table 2).

Table 2. Product portfolio positioning matrix

\begin{tabular}{|c|c|c|c|}
\hline Indicators & $s_{0}>s_{p}$ & $s_{0}=s_{p}$ & $s_{0}<s_{p}$ \\
\hline$r_{m}>r_{b}$ & 1 & 2 & 3 \\
\hline$r_{m=} r_{b}$ & 4 & 5 & 6 \\
\hline$r_{m<} r_{b}$ & 7 & 8 & 9 \\
\hline
\end{tabular}

Sources: developed by the author.

Now we introduce another element into the matrix - the net value of the commodity item/product group/brand or its share in the net value of the product portfolio. By the net value of the product/brand portfolio, we understand the part of the company's net cash flow that each product group/brand group generates. This is a part of the company's cash flow from operations. For formula development, we used an approach employed in marketing for determining net marketing effectiveness, which is used to evaluate the effectiveness of portfolio strategies, positioning, etc.

We propose the following simplified formula for the calculation:

$$
N P F_{\text {portfolio }}=\sum_{i=1}^{n} N C F_{i}
$$

where $\mathrm{NCF}_{i}$ - net cash flow, which is generated by the $i$ group of products of the product portfolio; $n-$ number of product groups/brands in the product portfolio.

Net cash flow, which is generated by the $i$ group of products, is calculated by the following formula:

$$
N C F_{i}=R_{i}-\mathrm{C}_{i}-M \& S_{i}
$$


where $R_{i}$ - revenue from the realization of products/brands of the $i$ group; $C_{i}-$ cost price of products/brands of the $i$ group; $M \& S_{i}-$ marketing and selling costs for products/brands of the $i$ group.

The net cash flow of the product/group of products/brand or its share in the product portfolio value (in $\%$ ) is presented in the matrix in a form of a circle diameter of which represents the respective item's value. Since the combinations of the selected characteristics include positions where the growth rate of the market is greater, less than or equal to the growth rate of the business, and the combinations of the planned and existing market share also suggest three options, the matrix will consist of nine quadrants. According to the matrix proposed the results of the analysis can be interpreted as follows:

1) product/product group/brand grows slower than the market, and the share decreases over time. These are problem products/product groups/brands that will most likely have to be eliminated;

2) product/product group/brand grows slower than the market, market share remains unchanged. Product/product group/brand is in an average competitive position. Additional investments are required to maintain the market share;

3) product/product group/brand grows slower than the market, market share increases over time. Product/product group/brand is in a neutral competitive position. A revision of the positioning strategy is required. Additional funds are required to maintain the market share growth;

4) product/product group/brand grows at the same rate as the market, the share decreases over time. Products/product groups/brands that fall into this quadrant are problematic, but they can be potentially moved (as a result of the revision of the development scenario) to another quadrant. A thorough analysis of the reasons for this and the process of decision making is required;

5) product/product group/brand grows at the same rate as the market, market share remains unchanged. This is a good product/product group/brand position. Usually, these are the products/product groups/brands that generate enough cash inflows and do not require additional investments;

6) product/product group/ brand grows at the same rate as the market, market share increases over time. Here are presented products/product groups/brands with good growth prospects, but they require significant additional investments;

7) product/product group/brand grows faster than the market, the share decreases over time. This means that consolidation processes might be taking place on the market, which requires the revision of the positioning strategy;

8) product/product group/brand grows faster than the market, market share remains unchanged. This is a product/product group/brand with a good competitive position, the positioning strategy has been chosen correctly;

9) product/product group/brand grows faster than the market, market share increases over time. This is a promising product/product group/brand with high growth potential. Additional investments are required to sustain their growth.

Products/product groups/brands that are in quadrants 1,2 and 4 have an insecure competitive position/value; those in quadrants 3,5 and 7 have average positions, and from a security standpoint their competitive position/value is ambiguous; for products/groups of products/brands that are in quadrants 6 , 8 and 9 , the competitive position/value is considered to be secure. The number of products/groups of products/brands that have secure competitive position/value should closely coincide with the proportions of the «golden ratio» concerning the rest.

In contrast to the «growth - market share» matrix, the growth rates of each product group/brand are compared with the market growth rate (the main trend of the economic sector) and the market share of each product group/brand in the reference and planning periods. This approach is more objective since the main trend considers all market players and presents an average indicator for the economic sector. If we only compare our data with the three biggest players on the market, then there may be too much of a 
leader of the key players and the evaluation will not be indicative. This is especially noticeable when there are one or two large players on the market. In our case, the market share of a product/product group/brand is compared in reference and planned periods, which allows us to link current positioning with the strategic goals of the company. Compared to the «growth - market share» matrix, where the criteria are determined by expert means and the probability of an «incorrect» assessment of the situation is quite high, the application of the proposed tool gives a much smaller margin of error since the evaluation excludes subjective factor. Developing a positioning matrix for the «MD» group of companies. Let us exemplify the building of the positioning matrix as an element of the general algorithm for determining the level of security of the product portfolio competitive position using the product portfolio of the «MD» (The names of the company and brands are changed, as it is an active player on the market) group of companies. The results of the analysis and data for the construction of the matrix are summarized in Table 3.

Table 3. Quantitative evaluation of the product portfolio of the «MD» group of companies for building a positioning matrix: the first iteration

\begin{tabular}{|c|c|c|c|c|c|c|}
\hline \multirow[t]{2}{*}{$\begin{array}{c}\text { Product } \\
\text { group/brand } \\
\text { portfolio }\end{array}$} & $\begin{array}{c}\text { Market } \\
\text { growth rate } \\
(2019 / 2016), \\
\%\end{array}$ & $\begin{array}{c}\text { Revenue } \\
\text { growth rate } \\
(2019 / 2016), \\
\%\end{array}$ & $\begin{array}{c}\text { Market } \\
\text { share in } \\
\text { the } \\
\text { referenc } \\
\text { e period } \\
(2016), \\
\%\end{array}$ & $\begin{array}{l}\text { Market share } \\
\text { in the } \\
\text { forecast } \\
\text { period } \\
(2019), \%\end{array}$ & \multirow[t]{2}{*}{$\begin{array}{l}\text { The net } \\
\text { value of } \\
\text { the food } \\
\text { group, } \$ \\
\text { thousands }\end{array}$} & \multirow[t]{2}{*}{$\begin{array}{l}\text { Product } \\
\text { group } \\
\text { share in } \\
\text { the } \\
\text { aggregat } \\
\text { e net } \\
\text { value, } \%\end{array}$} \\
\hline & $r_{m}$ & $r_{b}$ & $S_{0}$ & $S_{b}$ & & \\
\hline Soy sauce & 9 & 4,5 & 9,1 & 9 & 474584 & 34 \\
\hline Ginger & 25 & 28 & 28 & 28 & 318554 & 23 \\
\hline Rice & 9 & 8 & 30 & 29 & 13815 & 1 \\
\hline Ramen & 30 & 40 & 36,5 & 37 & 311652 & 23 \\
\hline Seaweed & 16 & 16 & 16 & 16 & 265167 & 19 \\
\hline \multicolumn{5}{|c|}{ PORTFOLIO TOTAL } & 1383772 & 100 \\
\hline
\end{tabular}

Sources: compiled according to data of the «MD» company group.

Note: the matrix is built according to the 2016 data with a forecast up to 2019.

The positioning matrix for the data presented in Figure 2. We only take data concerning grocery groups. This will be the top level of the product portfolio analysis. The diameter of the circle shows the share of the group of goods in the net value of the product portfolio. From figure 3 we can see the distribution of the value by quadrants is: $46 \%$ of the value of the portfolio is secure $(23 \%+23 \%)$ since the circles are in quadrants 8 and $9 ; 35 \%(34 \%+1 \%)$ refers to the insecure value (in quadrant 1$)$, and another $19 \%$ are in the area of unprotected value (the group of products is seaweed).

The distribution of the net value of the product portfolio according to the security level of the competitive position (Figure 3). The result is an inharmonious distribution of value within the portfolio since the proportion of secure to insecure value is far from the "golden ratio» (62\%: $38 \%)$. The groups of products in quadrant 1 are in the most vulnerable position: soy sauce and rice; the seaweed group of products in quadrant 5 falls under classification into the category of «ambiguous value». 


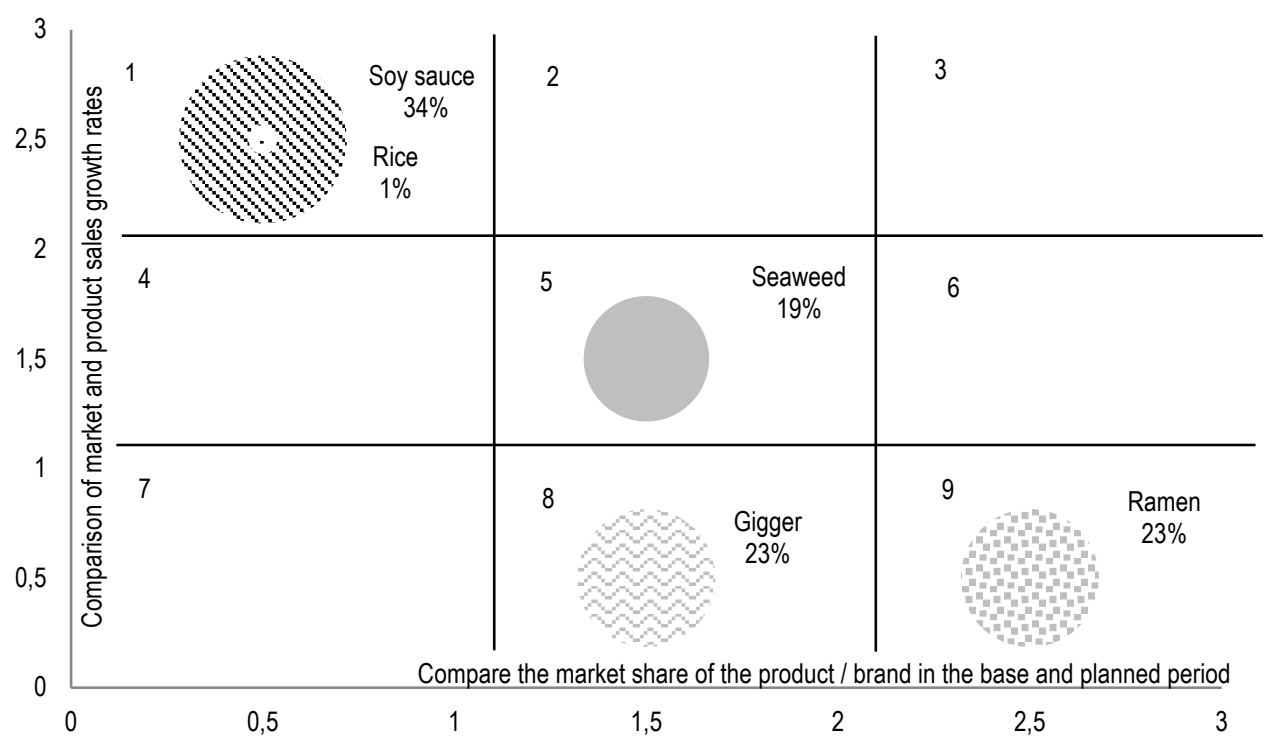

Figure 2. Positioning matrix for the product portfolio of the group of companies' «MD». The first

Sources: developed by the author. iteration

According to the algorithm for determining the level of security of the competitive position, we returned to its first step and began to revise the positioning of these product groups.

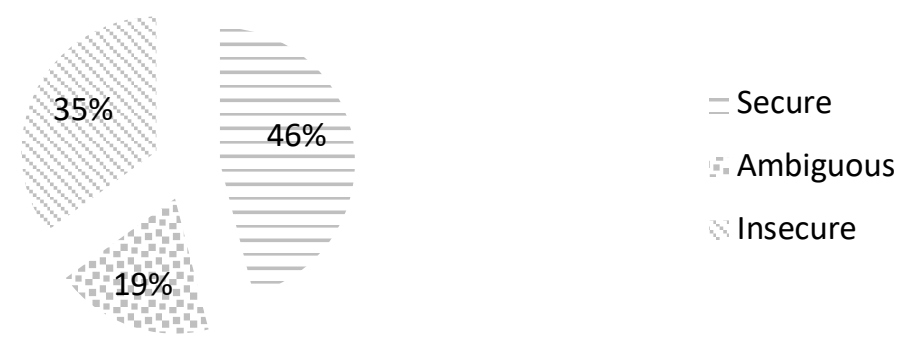

Figure 3. Security of the net value of the product portfolio/competitive position of the «MD» group of companies, forecast for 2019. First iteration

Sources: developed by the author.

First, we analysed the product groups that are in quadrants with insecure value: soy sauce and rice. These are the most challenging products for the group of companies concerning competition. These are markets with slow growth and strong players. For the «MD» group of companies, rice and soy sauce are the complementary groups of products for the core products (The proportion of core products concerning the complementary in the net portfolio value approximates the golden ratio: $65 \%$ : $35 \%$ ) - noodles, 
seaweed and ginger, that is, customers purchase these products together with the core products. Thus, it is impossible to give up these products. After that, the seaweed sales channels, sales volume by channels, and marketing activities were analysed. It turned out that the target audience was incorrectly identified and, consequentially, the share of sales by channels was calculated incorrectly as well. The company focused primarily on sales in the Retail channel (national networks). But this segment was not yet ready to accept this product in the volumes that had been planned. At the same time, the HoReCa segment showed a potentially large capacity. Seaweed sales volumes were adjusted by years and the potential market share for the planned period was recalculated, the new share growth rate was determined. After reviewing the marketing strategy and budgets, we recalculated the net value of the product seaweed group and the net cash flow of the entire product portfolio - and built the positioning matrix again (Table 4, Figure 4).

Table 4. Quantitative evaluation of the product portfolio of the «MD» group of companies for building a positioning matrix: second iteration

\begin{tabular}{|c|c|c|c|c|c|c|}
\hline \multirow[t]{2}{*}{$\begin{array}{l}\text { Product } \\
\text { group/brand } \\
\text { portfolio }\end{array}$} & $\begin{array}{c}\text { Market growth } \\
\text { rate } \\
(2019 / 2016), \%\end{array}$ & $\begin{array}{c}\text { Revenue } \\
\text { growth rate } \\
(2019 / 2016), \\
\%\end{array}$ & $\begin{array}{c}\text { Market share in } \\
\text { the reference } \\
\text { period (2016), } \\
\%\end{array}$ & $\begin{array}{c}\text { Market share } \\
\text { in the } \\
\text { forecast } \\
\text { period (2019), } \\
\% \\
\end{array}$ & \multirow[t]{2}{*}{$\begin{array}{c}\text { The net } \\
\text { value of the } \\
\text { food group, } \\
\$ \text { thousands }\end{array}$} & \multirow[t]{2}{*}{$\begin{array}{c}\text { Product } \\
\text { group share } \\
\text { in the } \\
\text { aggregate net } \\
\text { value, } \%\end{array}$} \\
\hline & $r_{m}$ & $r_{b}$ & $\mathrm{~S}_{0}$ & $S_{b}$ & & \\
\hline Soy sauce & 9 & 4,5 & 9,1 & 9 & 474584 & 33 \\
\hline Ginger & 25 & 28 & 28 & 28 & 318554 & 22 \\
\hline Rice & 9 & 8 & 30 & 29 & 13815 & 1 \\
\hline Ramen & 30 & 40 & 36,5 & 37 & 311652 & 21 \\
\hline Seaweed & 16 & 20 & 16 & 17 & 331459 & 23 \\
\hline \multicolumn{5}{|c|}{ PORTFOLIO TOTAL } & 1450064 & 100 \\
\hline
\end{tabular}

Sources: compiled according to data of the «MD» company group.

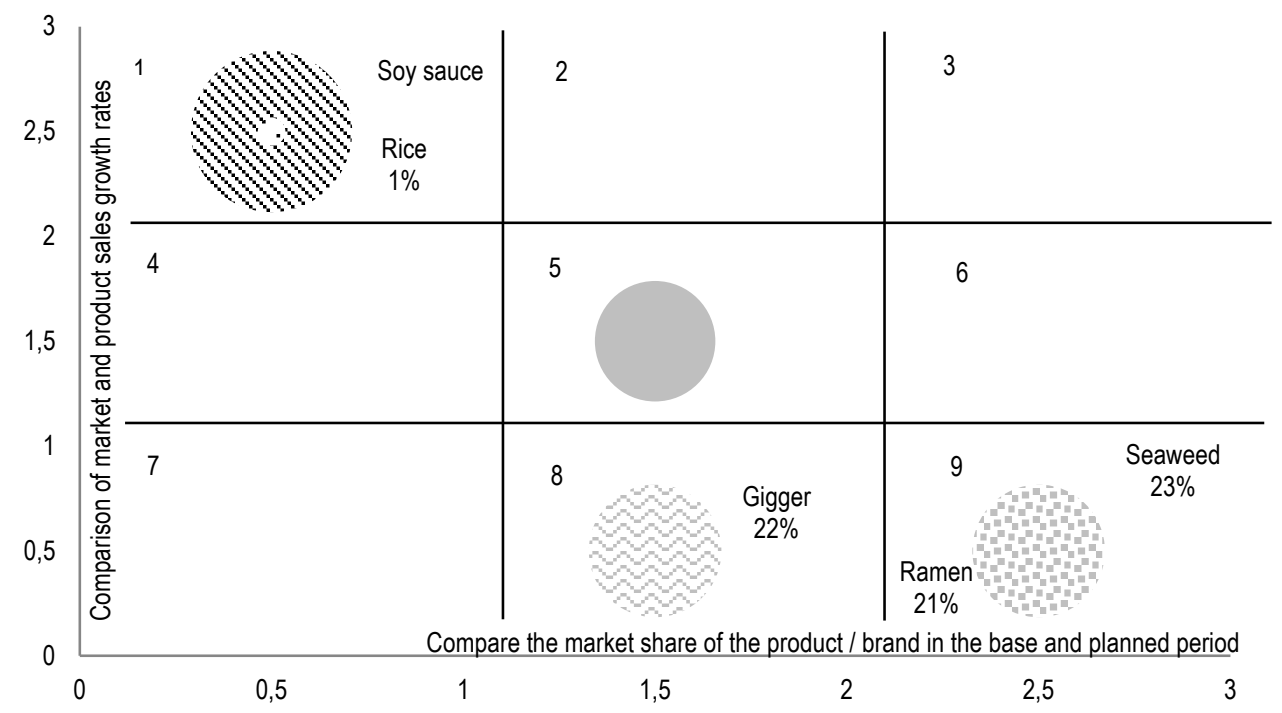

Figure 4. Positioning matrix for the product portfolio of the group of companies' «MD». The second iteration

Sources: developed by the author. 
The result is a developmental prospect with a more secure competitive position compared to the results of the first iteration, the ratio of secure value to insecure + ambiguous is $66 \%: 34 \%$. The proportion is close to balanced. The method of assessing the security of the competitive position made it possible to identify a group of products (seaweed), which required additional efforts on the behalf-marketing department. The further analysis of the product portfolio can be conducted utilizing factorial analysis of each product group in the context of specific products that form the value of this product group (see table). Similarly, you can analyse the product portfolio, shifting focus to the brands. In this case, you will have the brand/product group in the first column of the table. Further analysis is carried out similarly, but now you are working on a brand development strategy. The approach to building the structure of the product portfolio/brand portfolio from the standpoint of security of a competitive position/value creates an adaptation mechanism for managing the product portfolio, allowing the company to be confident on the market and build various strategies for developing product and brand portfolios.

Conclusions. The competitive position of the company's product/brand portfolio is a functional relation of the value of the business of the company. During the growth of business value, the competitive position of the product portfolio is strengthened and vice versa. To measure the balance of the product/brand portfolio we require a quantitative gauge-indicator. "Golden ratio» is proposed to be used as such an indicator. The product/brand portfolio is balanced if the proportion of the «golden ratio» $(62 \%: 38 \%)$ is observed in evaluating its structure (core and complementary or non-core product groups) and the ratio of the security value of the portfolio/competitive position to the remaining value of the portfolio/competitive position approximates proportions of the "golden ratio». For this study, we deem that business value/competitive position is secure from the perspective of competitive situation if the growth rate of the product portfolio group of products is equal to or higher than the growth rate of the market for this group of products and the market share for the group of products over time either remains at the same level or grows. To determine the level of security of the product portfolio competitive position, an algorithm has been proposed consisting of five basic stages of conducting organizational, economic, and statistical procedures within the context of solving the problem. For the same purpose, the positioning matrix has been developed. Positioning matrix is a tool for visual presentation of the strategic analysis of the product portfolio competitive position. The matrix compares business growth rates with a market share in the reference and planned periods. Since different combinations of the selected characteristics are possible when the market growth rate is greater, less than or equal to the business growth rate alongside with the combination of the planned and current market shares, there are three possible combinations, the interpretation of which is proposed to be applied on a practical level. The security of a competitive position in the context of our reasoning is a criterion of success and an assessment of the company's growth quality in general and a group of products/brands. Such an approach serves as the basis for developing company goal indicators in a specific time frame, estimated performance indicators of the company and its constituents, and top management motivational programs. Application of the «golden ratio» for the development of a product or brand portfolio makes goals measurable. The analysis of the product portfolio from the perspective of the competitive position security is suitable both for long-term planning and for achieving the company's short-term goals. Using the positioning matrix allows for the analysis of the development scenarios of the product portfolio, brand portfolio and creation of the development strategies for products/product groups/brands, development of the company's assortment policy. The positioning matrix allows one to evaluate the marketing and sales departments, as a comparison between the market growth rate and maintaining of the market share at the required level is taking place. Note that the limitation of this study is the fact that the proposed tool had been practically implemented only within three groups of companies. Although the author has been using this tool for ten years, it is necessary to continue the analysis of the applicability of this tool. Careful consideration in further studies should be given to the applicability of the approach and tool in critical situations. Besides, it is necessary to study the influence of the balance factor on the volume of the company's cash flow, alongside other factors that influence the growth of business value. 


\section{References}

Best, R. (2018). Marketing ot potrebitelia [Marketing from the consumer]. M.: Mann, Ivanov i Ferber [in Russian].

Erlih, A. (1996). Tekhnicheskij analiz tovarnyh I finansovyh rynkov [Technical Analysis Handbook for the Commodity and Financial Markets]. M.: INFRA-M [in Russian].

lasinskii, S.A. (2008). "Zolotoe» sechenie v standartizatsii $i$ teorii izmereniia ["Golden» section in the standardization and measurement theory]. SPb.: VAS [in Russian].

IFC rules. Retrieved from: URL: https://www.ifc.org/wps/wcm/connect/d6e5dd004d6fa1b085d1b548b49f4568/ECACR_OPRISK_training-RU.pdf?MOD=AJPERES.

Ivanus, A.I. (2012). Garmonichnoe upravlenie innovatsionnoi ekonomikoi v usloviiakh neopredelennosti [Harmonious management of innovative economy in conditions of uncertainty]. M.: Book house «LIBROKOM» [in Russian].

Hitskov, D.E. (2012). Algoritmy, metody I programmnye sredstva intellektualnoj podderzhki prinyatiya upravlencheskih reshenij $v$ ekonomicheskih sistemah holdingovogo tipa [Algorithms, methods and software tools of intellectual support of making managerial decisions in holding type economic systems]. Extended abstract of candidat's thesis: Voronezh [in Russian].

Kirillova, L.N., \& Ziyangulova A.R. (2010). Ispolzovanie principa zolotogo secheniya v garmonizacii struktury balansa predpriyatiya [Use of the golden section principle in the harmonization of the balance of the enterprise structure]. EconPapers, 17, 111-118 [in Russian].

Khutorskoi, P.A., \& Stepura, V.A. (2017). Metodicheskie aspekty upravleniia produktovym portfelem proizvodstvennogo predpriiatiia [Methodical aspects of managing the product portfolio of a manufacturing enterprise]. Eastern Europe: Economics, Business and Management, 6 (11), 189-194 [in Russian].

Korobko, V.I. (1998). Zolotaia proportsiia I problem garmonii sistem [Golden proportions and problems of harmony of systems]. M.: publishing house of the association of construction universities of the CIS countries [in Russian].

Kryuchkova, I. (2008). Strukturirovanie ekonomiki: dejstvie zakona zolotogo secheniya [Structuring the economy: the operation of the Golden Section Law]. Kiev: Institute of Evolutionary Economics. Retrieved from http://iee.org.ua/ru/publication/101/ [in Russian].

Kulinich, A. (2005). Plokhoi portfel' - odna iz prichin otsutstviia pribyli [A bad portfolio is one of the reasons for the lack of profit] Sales management, 6, 47-53 [in Russian].

Loginova, N.A., \& Nikitina I.A. (2015). Koncepciya «Zolotoe sechenie» kak osnova ekonomicheskoj bezopasnosti razvitiya transportnogo rynka [The concept of «Golden Section» as the basis of economic security of the transport market development]. service theory and practice, 2 (24), 61-64 [in Russian].

Mehrfi, Dzh.Dzh. (1996). Tekhnicheskij analiz f'yuchersnyh rynkov: teoriya I praktika [Technical Analysis of the Future Markets: a Comprehensive Guide to Trading and Methods and Applications]. M.: Sokol [in Russian].

Mintsberg, G. (2013). Strategicheskoe safari: Ekskursiia po debriam strategicheskogo menedzhmenta [Strategic Safari: Excursion to the Degree of Strategic Management]. M.: Al'pina Pablisher (Seriia «Skolkovo») [in Russian].

Pankova, N.V. (2013). Analiz innovacionnyh I rutinerskih processov v torgovle s pomoshyu proporcii Pareto I zolotoj proporcii Leonado da Vinchi [Analysis of innovative and routine processes in trade using the Pareto proportion and the golden proportion of Leonardo da Vinci]. Problems of modern economics, 4(48), 342-344 [in Russian].

Prangishvili, I.V., \& Ivanus A.I. (2004). Sistemnaya zakonomernost «zolotogo secheniya», sistemnaya ustoychivost I garmoniya [System regularity of the "golden section», system stability and harmony]. Management Problems, 2, 2-8 [in Russian].

Ren'I, A. (1980). Variatsii na temu Fibonachchi. Trilogiia o matematike [Variations on the theme of Fibonacci. A trilogy about mathematics]. M.: Mir [in Russian].

Semiglazov, A.M., \& Semiglazov V.A. (2009).K voprosu ispolzovaniya «zolotogo secheniya» v ekonomiko-upravlencheskih zadachah [To the question of using the «golden section» in economic and management problems]. Upravlenie, vychislitelnaya tehnika I informatika. Doklady TUSURA ,1(19), part 1, 162-167 [in Russian].

Shenyagin, V.P. (2013). Proyavlenie garmonii v ekonomike [The harmony manifestation in economy]. Economic Journal, 30, 30-45 [in Russian].

Shevelev, I.M., Marutaev, M.A., Shmelev, I.A. (1990). Zolotoe sechenie: tri vzglyada na prirodu garmonii [golden ratio: three views on the nature of harmony]. M.: Stroyizdat [in Russian].

Soroko, E.M. (2006). Zolotye secheniia, protsessy samoorganizatsiii evoliutsii sistem: Vvedenie v obshchuiu teoriiu garmonii sistem [Golden sections, processes of self-organization and evolution of systems: Introduction to the general theory of harmony of systems]. M.: Kom Kniga [in Russian].

Tompson, A.A. \& Striklend A.J. (1998). Otsenka diversifitsirovannogo portfelia s ispol'zovaniem matrichnogo analiza [Evaluation of a diversified portfolio with the use of matrix analysis]. M.: UNITI [in Russian].

Vlasova, L. (2006). Magicheskie chisla biznesa [Magical Business Numbers]. Ekonomika I zhizn, 37, 9147 [in Russian]

Dimovski, V., \& Uhan, M. (2012). Management from a natural perspective: Discovering the meaning of Fibonacci numbers for management. V: EBR 2012 2nd Annual Conference 2012. Ljubljana, November 29-30. [Work in progress]. Retrieved from https://editorialexpress.com/cgibin/conference/download.cgi?db_name=EBR2012\&paper_id=27(accessed:03.09.2018).

Dooly, R. Art, the Golden Mean, and the Brain. Retrieved from https://www.neurosciencemarketing.com/blog/articles/goldenmean-brain.htm. 
Lazareva, M. (2014). Innovative tools of a holding portfolio analysis: Positioning matrix. Economic Annals-XXI, 7-8(1), 80-83. McWhinnie, H.J. (1986). A review of the use of symmetry, the Golden Section and dynamic symmetry in contemporary art. The MIT Press, 19 (3), 241-245.

Nagji, B., Tuff G. (2012). Managing your innovation portfolio. Harvard Business Review, 90 (5), 66-74.

Nikolic, S.T., Cosic I., Pecujlija M., Miletic A. (2011). The effect of the «golden ratio» on consumer behavior. African Journal of Business Management, 5 (20), 8347-8360.

Pentago, C. 2018. Applying the Golden Ratio in Modern Designs. Hongkiat. Retrieved from https://www.hongkiat.com/blog/golden-ratio-in-moden-designs/.

Tabatabaei, M. (2016). The use of the Golden Ratio in the management for increased efficiency of resources. Retrieved from https://www.researchgate.net/project/The-use-of-the-Golden-Ratio-in-the-management-for-increased-efficiency-of-resources.

Thomas, P., Chrystal, A. (2013). Explaining the «Buy One Get One Free» promotion: The golden ratio as a marketing tool. American Journal of Industrial and Business Management, 3 (8), 655-673.

Seeger, J. A. (1984). Reversing the images of BCG's Growth Share Matrix. Strategic Management Journal, 5, 93-97.

Stakhov, A., Olsen, S. (2009). The Mathematics of Harmony - From Euclid to contemporary Mathematics and Computer Science. London: World Scientific Publishing Company. Series in Knots and Everything (Book 22).

М. Г. Лазарева, д.е.н., профресор, Національний університет «Києво-Могилянська академія» (Україна).

Матриця позиціонування як інструмент захищеності конкурентної позиції продуктового портфелю

Основною метою дослідження є розробка інструменту оцінки збалансованості продуктового портфеля компанії, за допомогою якого можна визначити захищеність його конкурентної позиції. У якості такого інструменту пропонується матриця позиціонування. У якості показника збалансованості продуктового портфеля виступає золотий перетин. Актуальність даного дослідження полягає в тому, що в даний час не існує загальноприйнятого критерію для визначення ступеня збалансованості продуктового портфелю, і що існуючі інструменти матричного аналізу не повністю забезпечують адекватну оцінку захищеності конкурентної позиції. Дослідження теми статmі здійснюється в наступній логічній послідовності: автор доводить правомірність використання золотого коефіцієнта як основного показника для оцінки збалансованості продуктового портфеля, а потім пропонує алгоритм оцінки визначення ступеню захищеності конкурентної позиції; далі автор розглядає сучасні методи оцінки продуктового портфеля, потім надає методику побудови матриці позиціонування та інтерпретації результатів з використанням практичних прикладів; далі йдуть висновки щодо застосовності запропонованого підходу та інструменту. У статті запропоновано авторський варіант вирішення питання оцінки захищеності конкурентної позиції продуктового портфеля. Розроблено інструмент аналізу портфеля матриця позиціонування, яка передбачає різне поєднання темпів зростання ринку та частки конкретної продукції / групи товарів / брендів на ній. У цьому випадку чиста вартість продуктового портфреля розраховується як фрункція бізнес-вартості компанії. Сфрормульовано критерії збалансованості товарного портфеля, які базуються на пропорції «золотого співвідношення». Конкурентна позиція продуктового портфеля буде захищена, коли темпи зростання продукту / групи товарів / бренду дорівнюють або перевищують темпи зростання ринку, а частка ринку для групи товарів з часом або залишається на тому ж рівні, або зростає. Результати дослідження можуть бути корисними для подальшого розвитку підходів та інструментів для оцінки конкурентної позиції компанії. Матриця позиціонування вже показала свій потенціал на практиці $і$ буде корисною при оцінці конкурентних позицій компанії у якості основного або допоміжного інструменту.

Ключові слова: збалансованість продуктового портфеля, золотий перетин, конкурентна позиція, матриця позиціонування, продуктовий портфель.

Manuscript received: 18.06.2019.

(C) The author(s) 2019. This article is published with open access at Sumy State University. 